\title{
Seasonal variations of $\mathrm{LH}$, prolactin, androstenedione, testosterone and testicular FSH binding in the male blue fox (Alopex lagopus)
}

\author{
A. J. Smith*, M. Mondain-Monval†, O. M. Møller*, R. Scholler† and \\ V. Hansson $\ddagger$
}

* Department of Animal Husbandry and Genetics, Norwegian College of Veterinary Medicine, P.O. Box 8146 Dep., 0033 Oslo 1, Norway; †Fondation de Recherche en Hormonologie, 67-77 boulevard

Pasteur, 94260 Fresnes, France; and $\ddagger$ Institutes of Pathology, Rikshospitalet, 0027 Oslo 1 and

Medical Biochemistry, P.O. Box 1112, Blindern, 0317 Oslo 3, Norway

\begin{abstract}
Summary. The seasonal changes in testicular weight in the blue fox were associated with considerable variations in plasma concentrations of LH, prolactin, androstenedione and testosterone and in FSH-binding capacity of the testis. An increase in LH secretion and a 5-fold increase in FSH-binding capacity were observed during December and January, as testis weight increased rapidly. LH levels fell during March when testicular weight was maximal. Plasma androgen concentrations reached their peak values in the second half of March (androstenedione: $0.9 \pm 0.1 \mathrm{ng} / \mathrm{ml}$; testosterone : $3.6 \pm 0.6 \mathrm{ng} / \mathrm{ml}$ ). A small temporary increase in LH was seen in May and June after the breeding season as testicular weight declined rapidly before levels returned to the basal state $(0 \cdot 5-7 \mathrm{ng} / \mathrm{ml})$ that lasted until December. There were clear seasonal variations in the androgenic response of the testis to LH challenge. Plasma prolactin concentrations $(2-3 \mathrm{ng} / \mathrm{ml})$ were basal from August until the end of March when levels rose steadily to reach peak values (up to $13 \mathrm{ng} / \mathrm{ml}$ ) in May and June just before maximum daylength and temperature. The circannual variations in plasma prolactin after castration were indistinguishable from those in intact animals, but LH concentrations were higher than normal for at least 1 year after castration.
\end{abstract}

\section{Introduction}

The male blue fox shows marked seasonal changes in testicular size and spermatogenic activity, which we have recently quantified with the aid of DNA flow cytometry (Smith et al., 1984). These changes are presumably brought about by the circannual changes in photoperiod which in turn regulate the secretion of pituitary hormones and their consequent effects on target organs (Lincoln \& Short, 1980). Studies on the males of a variety of other furbearing species have demonstrated circannual rhythms in the release of LH (e.g. red fox and badger: Maurel, Lacroix \& Boisson, 1984), prolactin (e.g. mink: Martinet, Ravault \& Meunier, 1982; red fox and badger: Maurel et al., 1984) and of androgens (e.g. mink: Boissin-Agasse \& Boissin, 1979; red fox: Maurel \& Boissin, 1981). In addition, marked variations in FSH secretion between different stages of reproductive activity have been reported for other seasonal breeders such as the ram (Lincoln, Almeida, Klandorf \& Cunningham, 1982). Studies on mink have examined the relationship between environmental cues (in particular photoperiod) and endocrine secretions (Allain, Martinet \& Rougeot, 1981; BoissinAgasse, Boissin \& Ortavant, 1982).

Previous studies on the reproductive endocrinology of the male fox are scarce and have been limited to a few measurements of plasma testosterone (Andersen, 1978; Nyberg, 1980) and 
testicular FSH binding (Andersen, Sundby \& Hansson, 1981). We have now developed specific radioimmunoassays for use in the blue fox for LH (Møller, Mondain-Monval, Smith, Metzger \& Scholler, 1984), prolactin (Mondain-Monval, Møller, Smith, McNeilly \& Scholler, 1985), androstenedione and testosterone (Møller et al., 1984), enabling a more complete investigation into the hormonal control of reproduction in this species and the relationship between endocrine events and the environment. These assays have so far only been used in the female blue fox.

The primary aim of the present study was to use these specific radioimmunoassays to establish the seasonal changes in plasma concentrations of two pituitary hormones (LH and prolactin), androstenedione and testosterone, and the FSH-binding capacity of the testis. In addition, we wished to relate the seasonal changes to the timing of the breeding season, environmental cues (daylength and temperature) and the seasonal variations in testicular size and cellular composition.

\section{Materials and Methods}

Animals. Eight farm-reared adult blue fox males aged $1 \frac{1}{2}-3$ years at the beginning of the study were housed individually outdoors on the Research Farm for Furbearing Animals, Heggedal, Norway (latitude: $59^{\circ} 47^{\prime} \mathrm{N}$; longitude: $10^{\circ} 27^{\prime} \mathrm{E}$ ). They were fed a ration of standard Norwegian wet feed (the main components being fish, slaughterhouse offal and concentrates) and were given water ad libitum. The males had visual and olfactory contact with vixens in other cages throughout the study. The breeding routines used on this farm have been described previously (Møller et al., 1984). The three annual breeding seasons during the 2-year sampling period occurred from 16 March to 5 May (mean: 21 March-29 April). The animals were subjected to light manual restraint (except when stated otherwise) for sampling purposes.

Collection of blood. Blood samples $(5-10 \mathrm{ml})$ were collected 1-5 times monthly into heparinized tubes from the cephalic vein between 09:00 and 11:00 h from February 1981 until April 1983: $>300$ blood samples were taken. Plasma was separated by centrifugation and stored at $-20^{\circ} \mathrm{C}$ until assay.

Blood samples $(4 \mathrm{ml})$ taken during anaesthesia (see below) were withdrawn into heparinized tubes via a Venflon cannula (Viggo AB, Helsingborg, Sweden) in the femoral vein. The red cells were pooled and stored at room temperature until intravenous re-injection once or twice during the experiment (always immediately after a blood sample) to help maintain circulating blood cell volume.

Two males were castrated at the height of one breeding season ( 7 April 1982) and were sampled for 1 year afterwards.

Anaesthesia. Four animals were anaesthetized to allow frequent sampling over an extended period once in the breeding season (6 April 1982) and once during sexual quiescence (27 July 1982). Samples were taken at least every $20 \mathrm{~min}$ for 3-7 h. In addition, two of the males were anaesthetized once in January 1983 (during the period of testicular redevelopment) for 5-6 h. The steroid mixture Saffan (Glaxovet, Greenford, Middlesex, England; $9 \mathrm{mg}$ alphaxalone $/ \mathrm{ml}, 3 \mathrm{mg}$ alphadolone/ml) was used as the anaesthetic to minimize disturbances to neuroendocrine function (Timms, 1981; Clarke \& Doughton, 1983). The animals were premedicated with $5 \mathrm{mg}$ dexachlorpheniramine maleate (Phenamin, Nyco, Oslo, Norway) given subcutaneously $20 \mathrm{~min}$ before induction of anaesthesia to prevent possible histamine release as seen with this anaesthetic in dogs (Child et al., 1971). This premedication has no effect on plasma concentrations of $\mathrm{LH}$, prolactin or androgens in the male blue fox (unpublished results). After induction, aliquants ( $1 \mathrm{ml})$ of anaesthetic were given intravenously every $20 \mathrm{~min}$. Towards the end of each period of anaesthesia (after at least $100 \mathrm{~min}$ ), the foxes were given a rapid intravenous injection of LHRH $(2 \cdot 1 \mu \mathrm{g}$ buserelin acetate; Hoechst, Frankfurt am Main, West Germany) and sampling continued every $10 \mathrm{~min}$ for $70-110 \mathrm{~min}$. 
Hormone assays. The radioimmunoassays for $\mathrm{LH}$, androstenedione and testosterone (Møller et al., 1984) and for prolactin (Mondain-Monval et al., 1985) have been described and validated for the blue fox previously. The sensitivities of the assays (minimum detectable from zero) were $0.4 \mathrm{ng}$ $\mathrm{LH} / \mathrm{ml}, 30 \mathrm{pg}$ androstenedione $/ \mathrm{ml}, 20 \mathrm{pg}$ testosterone $/ \mathrm{ml}$ and $1 \mathrm{ng}$ prolactin $/ \mathrm{ml}$. The intra- and interassay coefficients of variation were, respectively, 7.3 and $10 \%$ for $\mathrm{LH}, 8.4$ and $11.7 \%$ for androstenedione, 8.9 and $11.8 \%$ for testosterone and 8.0 and $13.0 \%$ for prolactin.

Measurement of FSH binding. Adult male blue foxes $(\mathrm{N}=46)$ were castrated under intravenous pentobarbitone sodium anaesthesia at approximately monthly intervals from November 1981 to October 1982, with the exception of the 6 animals castrated in November from which the testes were removed at pelting, $\sim 20 \mathrm{~min}$ after death. After weighing, the testes were cut into small pieces and frozen on solid $\mathrm{CO}_{2}$ before storage at $-70^{\circ} \mathrm{C}$. Weighed testicular tissue $(\sim 250 \mathrm{mg})$ from each fox in the group was pooled for determination of FSH binding as described previously (Hansson $e t$ al., 1978). The specific binding (mean of triplicate determinations) for the pooled testicular material ( $10 \mathrm{mg}$ tissue per assay tube) was first converted to fmol FSH bound and then corrected for the mean testicular weight of all the foxes in each group. Iodinated human FSH has previously been shown to bind specifically to receptors in the blue fox testis (Andersen et al., 1981).

Miscellaneous. The data on daylength and temperature were supplied by the Institute for Astrophysics, Oslo, and the Meteorological Institute, Blindern, Oslo, respectively. For statistical purposes the data were examined by one-way analysis of variance and Student's $t$ test. All means are expressed as \pm S.E.M.

\section{Results}

Seasonal variations in daylength, temperature and testicular weight

The circannual variations in daylength, temperature and testis weight are depicted in Text-figs 1 (a) and l(b). Testicular weights began to increase about 5 months before the breeding season and were maximal in mid-March. The sharp decline in testicular weight which began during the breeding season occurred as daylength and environmental temperature increased towards their respective maxima.

\section{Prolactin}

Prolactin concentrations (Text-fig. 1c) were low from August to March (range $1.4-5.5 \mathrm{ng} / \mathrm{ml}$, mean $3.1 \mathrm{ng} / \mathrm{ml} ; 193$ samples). Values in April were significantly elevated $(P<0.01)$ and concentrations were maximal in May and June (range $3 \cdot 3-13.4 \mathrm{ng} / \mathrm{ml}$, mean $7.0 ; 48$ samples). A significant $(P<0.01)$ fall in mean prolactin concentrations then occurred in July.

\section{FSH binding}

Specific FSH-binding capacity expressed per testis was low from July to December (range 7-20, mean $12.1 \mathrm{fmol} /$ testis) but increased 5 -fold between December and January (to $70 \mathrm{fmol} /$ testis) before gradually declining again until June (Text-fig. 2a).

\section{$L H$}

Plasma LH concentrations (Text-fig. 2b) showed considerable individual variations at most times of the year. From August to the first half of November, mean values were generally low $(2.0 \pm 0.8 \mathrm{ng} / \mathrm{ml})$ and concentrations for many of the samples were below the limit of detection $(0.4$ $\mathrm{ng} / \mathrm{ml})$. A marked increase $(P<0.01)$ in $\mathrm{LH}$ concentrations was seen in December compared to 

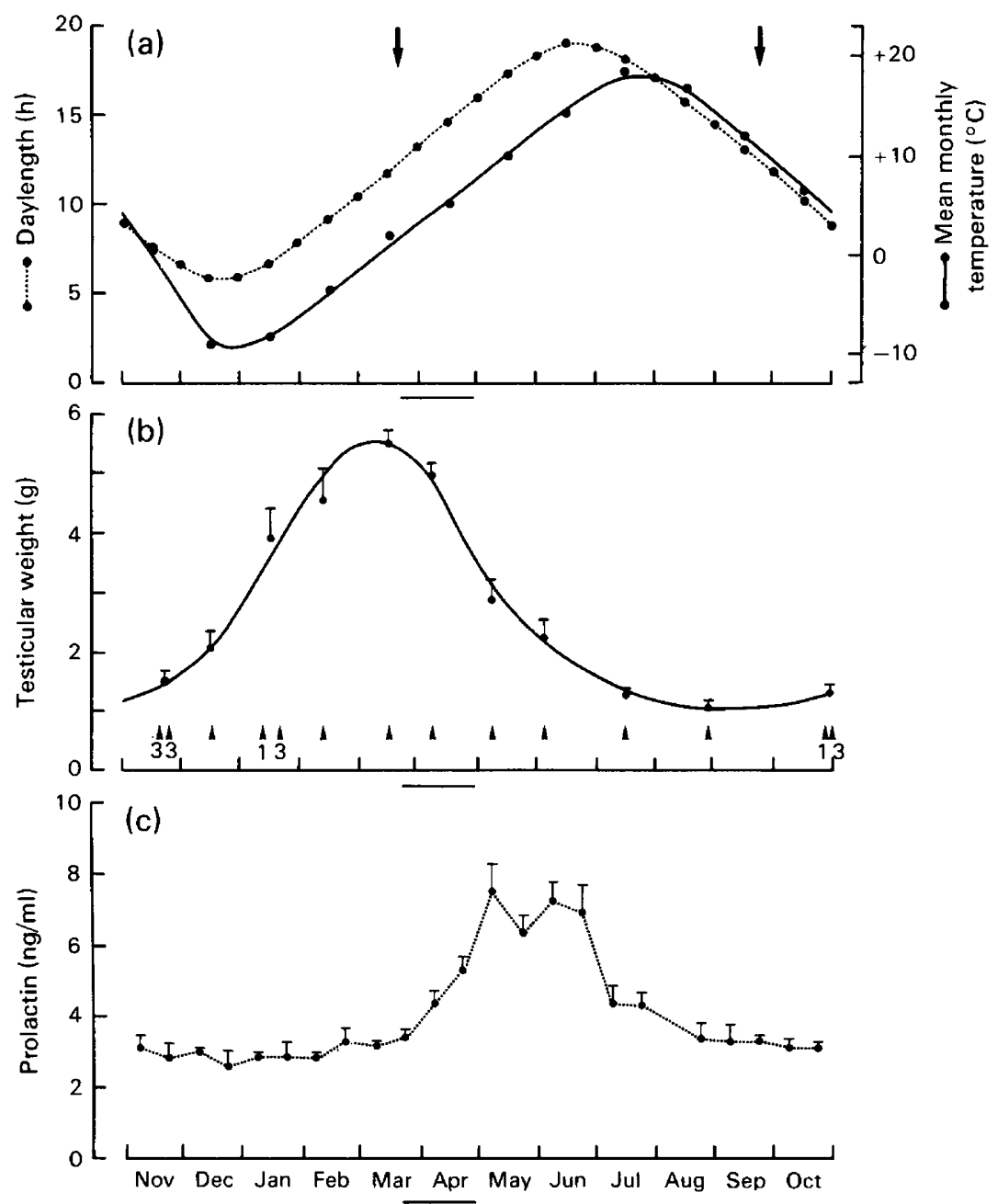

Text-fig. 1. Seasonal changes in (a) daylength and mean monthly temperature, (b) testicular weight and (c) plasma prolactin concentrations. The arrows in (a) depict the spring and autumnal equinoxes (21 March and 23 September respectively). The data on testicular weight (means + s.e.m.) are taken from Smith et al. (1984) and comprise 46 blue fox males castrated at approximately monthly intervals as indicated by the arrowheads, in groups of 4 unless otherwise stated. The prolactin values (means + s.e.m. of 305 samples) are from 8 adult males sampled 1-5 times monthly over a 2-year period. The horizontal bars represent the mean length of the 3 breeding seasons during the study.

values in July-November (range, not detectable $-116.5 \mathrm{ng} / \mathrm{ml}$, mean $10.5 \pm 4.6 ; 27$ samples) and all LH values from December to July were above the limit of detection. Plasma concentrations were still high in May and June (range, not detectable $-35.3 \mathrm{ng} / \mathrm{ml}$, mean $7.9 \pm 1.4 ; 48$ samples) as plasma androgen concentrations returned to basal levels (see Text-fig. 3).

\section{Androstenedione and testosterone}

The mean plasma concentrations of androstenedione and testosterone (Text-fig. 3) showed basal values $(<0.7 \mathrm{ng} / \mathrm{ml}$ ) from July until the end of November. Concentrations of both androgens then began to increase steadily from about 3 months before the onset of the breeding season, to 


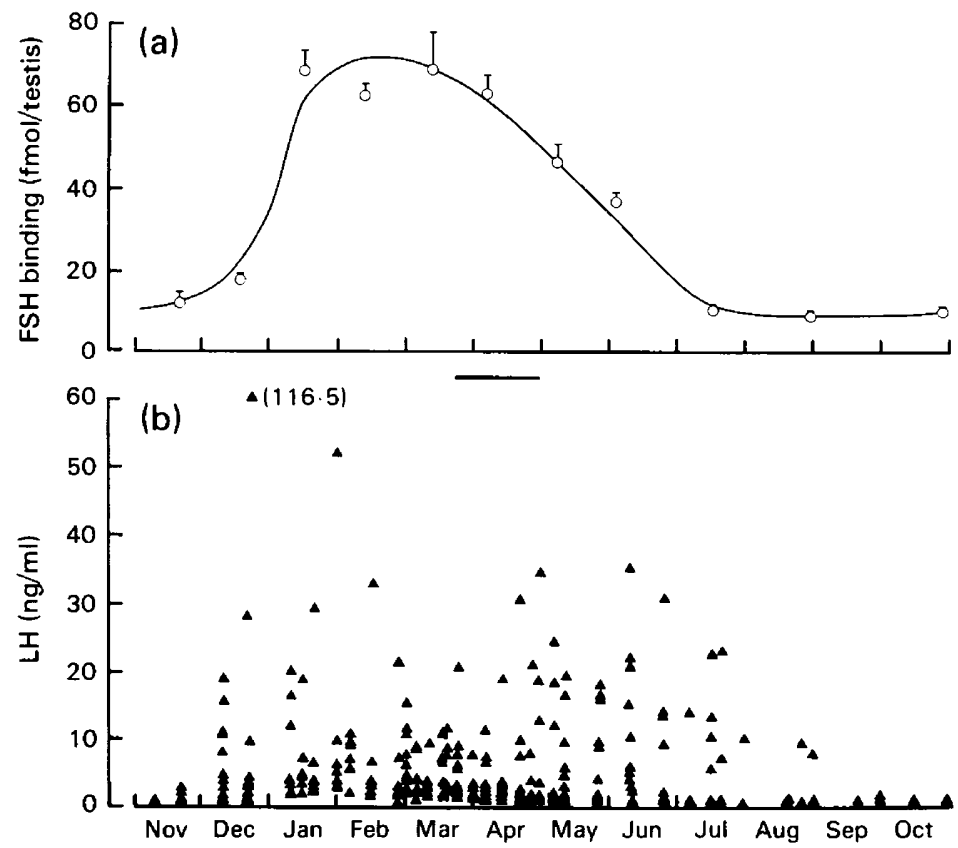

Text-fig. 2. Seasonal changes in (a) total testicular FSH-binding capacity and (b) plasma LH concentrations in the male blue fox. FSH binding was measured for the testes described in Text-fig. 1(b) and the values are means + s.e.m. of triplicate determinations. The LH values are from the 8 individuals in Text-fig. 1(c) sampled 1-5 times monthly over a 2-year period (305 samples). The horizontal bar represents the mean length of the breeding seasons during the study.

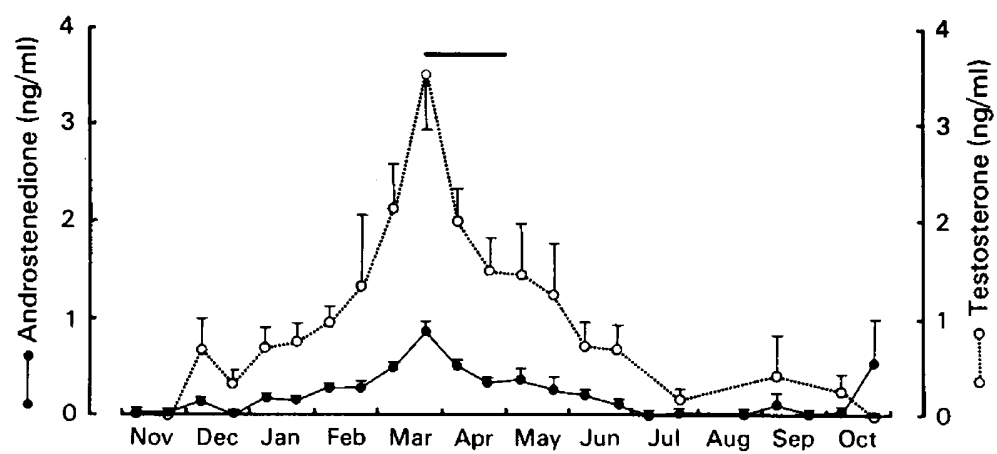

Text-fig. 3. Seasonal changes in plasma androstenedione and testosterone concentrations in the male blue fox. Values are means \pm s.e.m. of 305 samples collected from 8 individuals $1-5$ times monthly over a 2-year period (see also Text-figs 1c \& 2). The horizontal bar represents the mean length of the breeding seasons during the study.

reach peak mean values in the second half of March (androstenedione: $0.9 \pm 0.1 \mathrm{ng} / \mathrm{ml}$; testosterone: $3.6 \pm 0.6 \mathrm{ng} / \mathrm{ml}$ ). Plasma concentrations then declined to basal values by July. The mean testosterone levels were greater than those of androstenedione at all times of the year except the second half of October and the first half of November. 


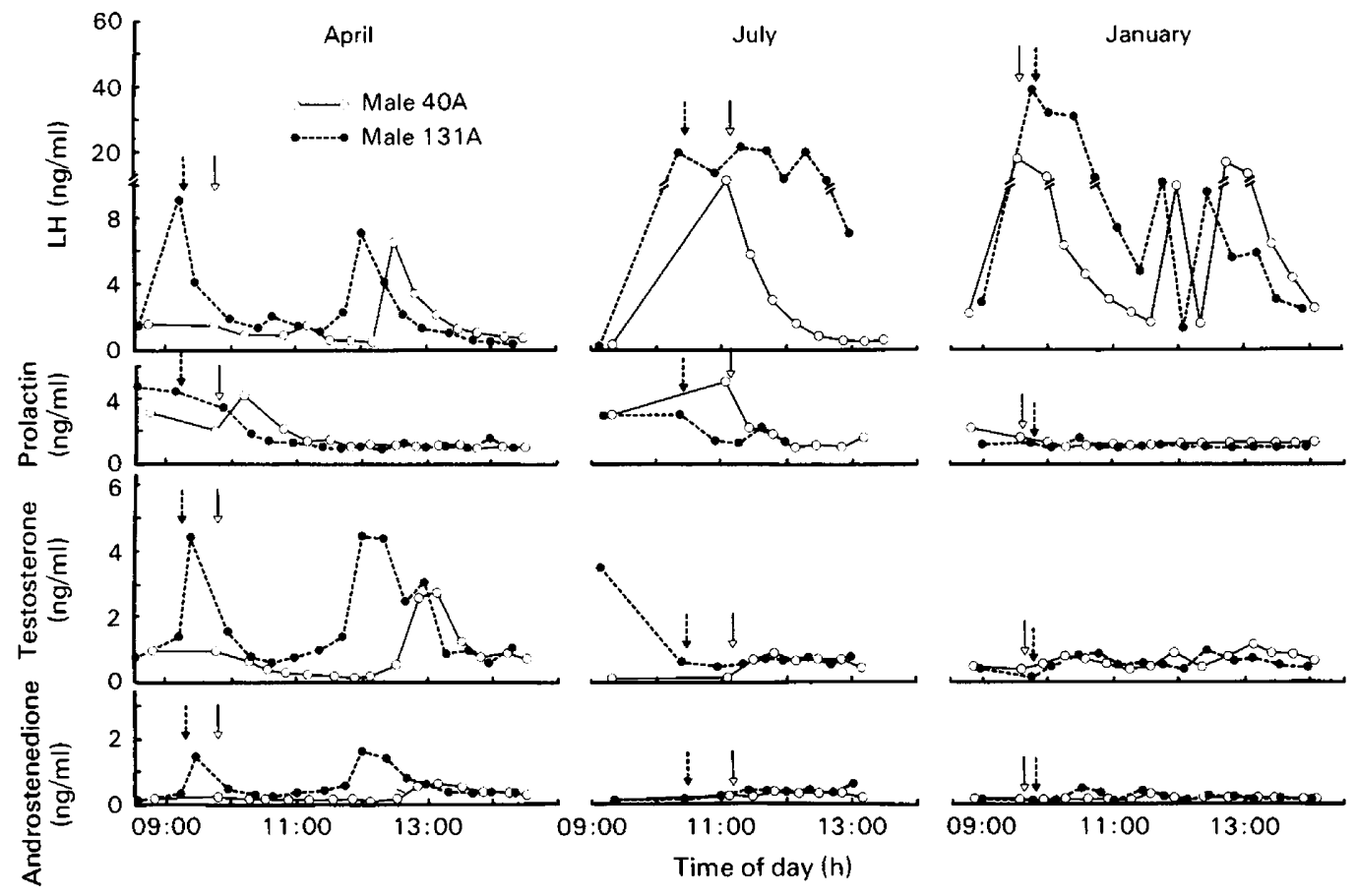

Text-fig. 4. Short-term changes in plasma concentrations of LH, prolactin, testosterone and androstenedione (single samples) in 2 anaesthetized male blue foxes at three times of the year. The arrows indicate the time of induction of anaesthesia.

\section{Short-term release of plasma hormones}

Text-figure 4 shows plasma concentrations of $\mathrm{LH}$, prolactin, testosterone and androstenedione in 2 of the animals anaesthetized at 3 times of the year, coinciding with the sexually quiescent state (July), testicular development (January) and sexual maturity (April). The episodic nature of LH release was evident at all three stages with a tendency for levels to be depressed in April. Prolactin levels were generally stable. Plasma levels of androstenedione and testosterone were low $(<1$ $\mathrm{ng} / \mathrm{ml}$ ) in July and January, despite episodic LH peaks of $20-30 \mathrm{ng} / \mathrm{ml}$. High concentrations of LH were observed in one male (131A) in July but there was no clear androgen response. In April, however, both androgens showed pulsatile secretion synchronous with LH increases. Androstenedione secretion tended to mirror that of testosterone but at lower concentrations.

\section{Seasonal changes in hormone response to $L H R H$ injection}

The effects of rapid intravenous LHRH injections on plasma concentrations of $\mathrm{LH}$ and testosterone in anaesthetized males at 3 times of the year are shown in Text-fig. 5. LH concentrations rose within $10 \mathrm{~min}$ of injection in all foxes and there did not appear to be marked seasonal variations in the response of the pituitary to LHRH, although the 2 animals sampled in January showed the greatest LH release. There were, however, clear seasonal variations in the ability of the testis to respond to an LH challenge by the release of androgens. In July and January, there was no significant increase in testosterone concentrations $(P>0.05)$. In April, however, a rapid elevation $(P<0.01)$ of plasma testosterone was observed after injection of LHRH, simultaneously with the LH rise, reaching values 5-20 times the pre-stimulation levels $40-50 \mathrm{~min}$ after injection. A gradual decline in $\mathrm{LH}$ and testosterone concentrations was then observed. Plasma 


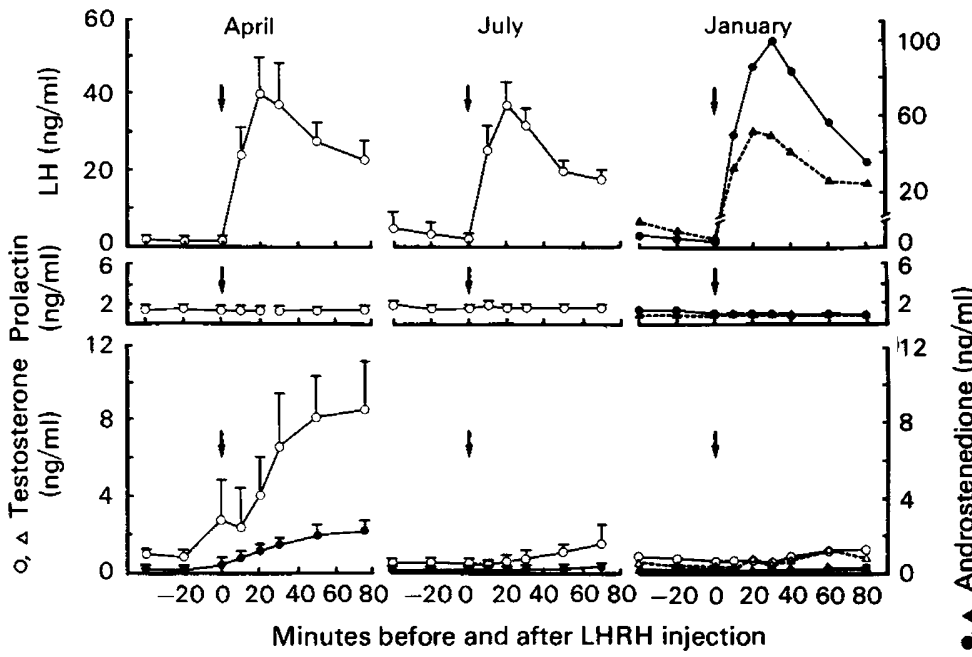

Text-fig. 5. Plasma concentrations of $\mathrm{LH}$, prolactin, testosterone and androstenedione after LHRH challenge in 4 anaesthetized male blue foxes at three times of the year. The arrows depict the time of injection of LHRH. The values in April and July are means + s.e.m. of 4 animals, while those in January are single samples from 2 individuals.

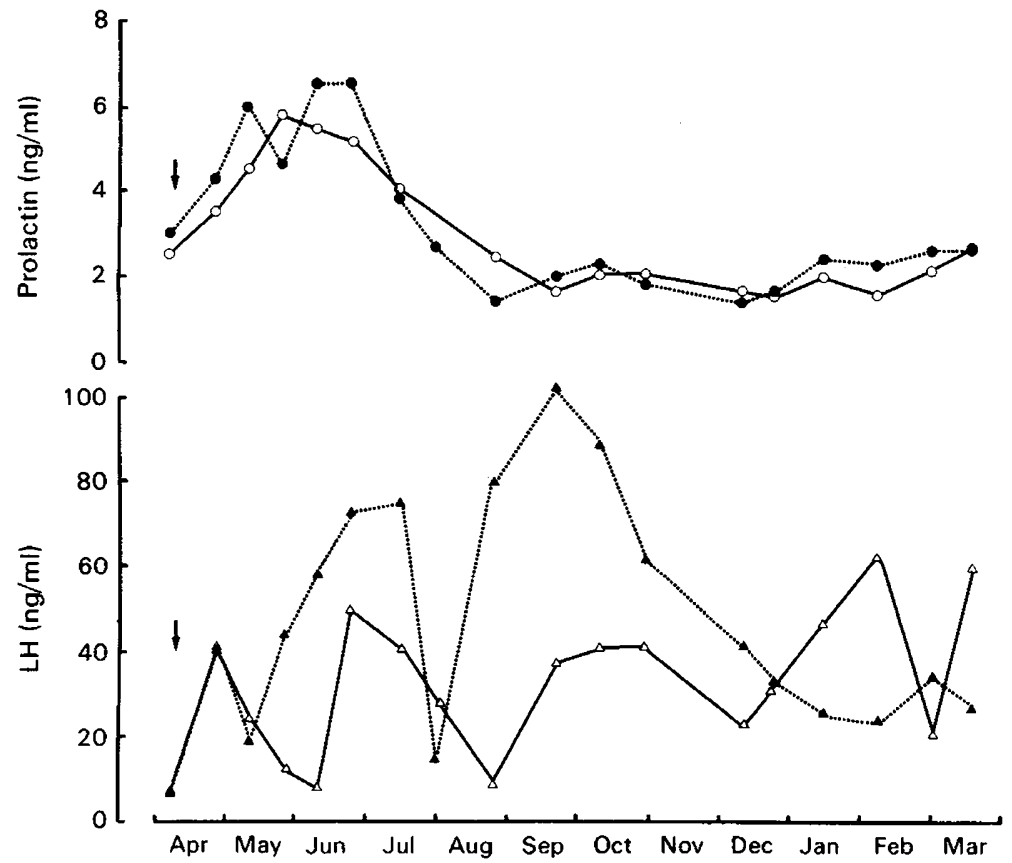

Text-fig. 6. Plasma concentrations (single samples) of $\mathrm{LH}$ and prolactin in 2 male blue foxes sampled for 1 year after castration in April.

concentrations had not returned to basal levels $70-80 \mathrm{~min}$ after injection. Prolactin values were unaffected by injection of LHRH.

\section{Effects of castration}

The seasonal changes in prolactin secretion after castration (Text-fig. 6, top panel) were indistinguishable from those in intact animals (see Text-fig. 1c). LH concentrations were, however, 
elevated and fluctuated from around 10 to $100 \mathrm{ng} / \mathrm{ml}$ (Text-fig. 6 , bottom panel). No clear seasonal variations in secretion were observed and measurements during any one month on the same individual often varied considerably.

\section{Discussion}

Testicular redevelopment, judged by changes in testis size, cell composition and ultrastructure (Andersen, 1978; Smith et al., 1984) begins about 5 months before the testes reach full maturity at the onset of the breeding season (mid-March, Text-fig. 1b). However, a significant increase in FSH-binding capacity of the testis (Text-fig. 2a) or plasma gonadotrophin (LH) concentrations (Text-fig. 2b) is not seen until December when redevelopment is well underway, although a more detailed study of this period is warranted. It has not yet been possible to measure $\mathrm{LH}$ receptors in the blue fox testis since there is no specific binding of iodinated human LH (Andersen et al., 1981). A complete assessment of the hormonal events during the onset of testicular redevelopment must also await the establishment of an assay for plasma FSH in the blue fox, since a considerable increase in concentrations occurs in other seasonal breeders at this time (e.g. ram: Lincoln, 1978). However, despite the establishment of a role for FSH during puberty, the importance of FSH secretion in the mature animal or in seasonal breeders is still unknown (Davies, 1981).

LH secretion is episodic at all times of the year in most mammals and this complicates interpretation of seasonal changes in release (Katongole, Naftolin \& Short, 1974). There was no evidence of large seasonal changes in LH response to LHRH injection as shown in the ram (Lincoln, 1976). One possible reason for this is the higher dose of LHRH used in the present study.

The regulation of testicular regression remains unclear. The earliest signs of regression as judged by a decline in production of haploid cells (Smith et al., 1984) occur at the onset of the breeding season (mid-March), which coincides with the spring equinox. Changes in photoperiod may therefore play a central role in the regulation of testicular regression. Since LH levels were still high in the initial stages of testicular regression (late April to June, Text-fig. 2b) during the removal of negative androgen feedback, the subsequent fall in August must be due to other factors, such as an increased sensitivity of the hypothalamic-pituitary axis to the inhibitory effect of androgens, or a reduced sensitivity of Leydig cells to $\mathrm{LH}$.

Although testicular regression coincides with the annual increase in prolactin secretion, the two are unlikely to be closely related. Peak prolactin concentrations occur simultaneously (in May and June) in the blue fox (present study), silver fox, racoon dog (unpublished data) and red fox (Maurel et al., 1984), which undergo testicular regression at different times after the winter solstice. Studies on other seasonal breeders such as sheep, for which there are breed differences in the onset of the season (Carr \& Land, 1982), also support this conclusion. Likewise, there was no clear association between prolactin concentrations and any of the other hormones examined in the present study (Text-fig. 4) and the seasonal changes in prolactin secretion continued after castration (Text-fig. 6). Any physiological role for prolactin in the control of seasonal reproductive activity in the male blue fox remains to be found. Indeed, our current research (data to be published) indicates that the seasonal changes in testicular size continue regardless of plasma prolactin concentrations and that prolactin plays a central role in the regulation of the annual moulting cycle.

Changes in the secretion of gonadotrophins in response to changes in photoperiod are seen in many seasonal breeders (Ortavant, Mauleon \& Thibault, 1964; Lincoln \& Short, 1980). The observation in the present study (Text-fig. 2) that plasma LH concentrations and FSH-binding capacity of the testis do not increase until after the onset of redevelopment suggests the presence of an intermediate factor linking daylength and gonadotrophin secretion. Pineal secretions, in particular melatonin, may provide this link by controlling the overall concentrations of the hormones secreted by the anterior pituitary (Lincoln, Almeida \& Arendt, 1981; Lincoln et al., 1982). Melatonin implants in sexually inactive male mink have been shown to advance testicular redevelopment (Allain et al., 1981). 
The seasonal fluctuations in plasma prolactin levels are clearly not dependent upon the presence of functional testes. The pattern of $\mathrm{LH}$ secretion was, however, considerably altered by castration, and the elevated concentrations with no clear annual variations suggest that negative androgen feedback operates at all times of the year in intact animals. These high LH levels are probably maintained by frequent, large peaks of release (Lincoln \& Kay, 1979).

In conclusion, the present study provides for the first time information on the circannual changes in concentrations of various hormones which are likely to be of importance in regulating the seasonal changes in testicular function in the blue fox. Further studies are, however, needed to investigate the role of photoperiod, the relative importance of the hormones examined in this study and the mechanisms by which external and internal cues influence the hypothalamic-pituitary axis.

We thank Drude Andersen, Reidun Andersen, Reidar Haugen and Patricia Simon for skilful technical assistance and Aslaug Skiaker for typing the manuscript. The present study was supported by the Rockefeller Foundation, the Norwegian Council for Science and the Humanities (NAVF) and the Norwegian Society for Fighting Cancer.

\section{References}

Allain, D., Martinet, L. \& Rougeot, J. (1981) Effect of melatonin implants on the coat, plasma prolactin levels and testis cycle in the mink (Mustela vison). In Photoperiodism and Reproduction, pp. 263-271. Eds R. Ortavant, J. Pelletier \& J. P. Ravault. INRA, Nouzilly.

Andersen, K. (1978) Seasonal change in fine structure and function of Leydig cells in the blue fox (Alopex lagopus). Int. J. Androl. 1, 424-439.

Andersen, K., Sundby, A. \& Hansson, V. (1981) Fine structure and FSH binding of Sertoli cells in the blue fox (Alopex lagopus) in different stages of reproductive activity. Int. J. Androl. 4, 570-581.

Boissin-Agasse, L. \& Boissin, J. (1979) Variations saisonnières du volume testiculaire et de la testostéronémie chez deux mustélidés: le Furet (Mustela furo L.) et la Vison (Mustela vison S.). J. Physiol. (Paris) 75, 227-232.

Boissin-Agasse, L., Boissin, J. \& Ortavant, R. (1982) Circadian photosensitive phase and photoperiodic control of testis activity in the mink (Mustela vison Peale and Beauvois), a short day mammal. Biol. Reprod. 26, 110-119.

Carr, W.R. \& Land, R.B. (1982) Seasonal variation in plasma concentrations of prolactin in castrated rams of breeds of sheep with different seasonality of reproduction. J. Reprod. Fert. 66, 231-235.

Child, K.J., Currie, J.P., Davis, B., Dodds, M.G., Pearce, D.R. \& Twissell, D.J. (1971) The pharmacological properties in animals of CT1341-a new steroid anaesthetic agent. Br. J. Anaesth. 43, 2-13.

Clarke, I.J. \& Doughton, B.W. (1983) Effect of various anaesthetics on resting plasma concentrations of luteinizing hormone, follicle-stimulating hormone and prolactin in ovariectomized ewes. $J$. Endocr. 98 , 79-89.

Davies, A.G. (1981) Role of FSH in the control of testicular function. Archs Androl. 7, 97-108.

Hansson, V., Purvis, K., Attramadal, A., Torjesen, P., Andersen, D. \& Ritzen, E.M. (1978) Sertoli cell function in the androgen insensitive ( $\mathrm{Tfm}$ ) rat. Int. J. Androl. 1, 96-104.

Katongole, C.B., Naftolin, F. \& Short, R.V. (1974) Seasonal variations in blood luteinizing hormone and testosterone levels in rams. $J$. Endocr. 60, 101-106.

Lincoln, G.A. (1976) Seasonal variation in the episodic secretion of luteinizing hormone and testosterone in the ram. J. Endocr. 69, 213-226.

Lincoln, G.A. (1978) The temporal relationship between plasma levels of FSH and $\mathrm{LH}$ in the ram. $J$. Reprod. Fert. 53, 31-37.

Lincoln, G.A. \& Kay, R.N.B. (1979) Effects of season on the secretion of $\mathbf{L H}$ and testosterone in intact and castrated red deer stags (Cervus elaphus). J. Reprod. Fert. 55, 75-80.

Lincoln, G.A. \& Short, R.V. (1980) Seasonal breeding: Nature's contraceptive. Recent Prog. Horm. Res. 36, $1-51$.

Lincoln, G.A., Almeida, O.F.X. \& Arendt, J. (1981) Role of melatonin and circadian rhythms in seasonal reproduction in rams. $J$. Reprod. Fert., Suppl. 30, 2331.

Lincoln, G.A., Almeida, O.F.X., Klandorf, H. \& Cunningham, R.A. (1982) Hourly fluctuations in the blood levels of melatonin, prolactin, luteinizing hormone, follicle-stimulating hormone, testosterone, tri-iodothyronine, thyroxine and cortisol in rams under artificial photoperiods, and the effects of cranial sympathectomy. J. Endocr. 92, 237-250.

Martinet, L., Ravault, J.P. \& Meunier, M. (1982) Seasonal variations in mink (Mustela vison) plasma prolactin measured by heterologous radioimmunoassay. Gen. comp. Endocr. 48, 71-75.

Maurel, D. \& Boissin, J. (1981) Plasma thyroxine and testosterone levels in the red fox (Vulpes vulpes L.) during the annual cycle. Gen. comp. Endocr. 43, 402404.

Maurel, D., Lacroix, A. \& Boissin, J. (1984) Seasonal reproductive endocrine profiles in two wild mammals : the red fox (Vulpes vulpes $L$.), and the European 
badger (Meles meles L.) considered as short-day mammals. Acta endocr., Copenh. 105, 130-138.

Meller, O.M., Mondain-Monval, M., Smith, A., Metzger, E. \& Scholler, R. (1984) Temporal relationships between hormonal concentrations and the electrical resistance of the vaginal tract of blue foxes (Alopex lagopus) at pro-oestrus and oestrus. J. Reprod. Fert. 70, 15-24.

Mondain-Monval, M., Meller, O.M., Smith, A.J., McNeilly, A.S. \& Scholler, R. (1985) Seasonal variations of prolactin and $\mathrm{LH}$ in the blue fox female. J. Reprod. Fert. 74, 439-448.

Nyberg, K. (1980) Crossing blue fox (Alopex lagopus) to red fox (Vulpes vulpes) using artificial insemination. Nord. VetMed. 32, 132-138.
Ortavant, R., Mauleon, P. \& Thibault, C. (1964) Photoperiodic control of gonadal and hypophyseal activity in domestic animals. Ann. N.Y. Acad. Sci. 117, 157-193.

Smith, A.J., Clausen, O.P.F., Kirkhus, B., Jahnsen, T., Meller, O.M. \& Hansson, V. (1984) Seasonal changes in spermatogenesis in the blue fox (Alopex lagopus), quantified by DNA flow cytometry and measurement of soluble $\mathrm{Mn}^{2+}$-dependent adenylate cyclase activity. J. Reprod. Fert. 72, 455-461.

Timms, R.J. (1981) A study of the amygdaloid defence reaction showing the value of Althesin anaesthesia in studies of the functions of the fore-brain in cats. Pflugers Arch. ges. Physiol. 391, 49-56.

Received 22 August 1984 